Marquette University

e-Publications@Marquette

8-9-2010

Chain-Selective and Regioselective Ethylene and Styrene Dimerization Reactions Catalyzed by a Well-Defined Cationic Ruthenium-Hydride Complex: New Insights on the Styrene Dimerization Mechanism

Do W. Lee

Marquette University, do.lee@marquette.edu

Chae S. Yi

Marquette University, chae.yi@marquette.edu

Accepted version. Organometallics, Vol. 29, No. 15 (August 2010): 3413-3417. DOI. (C) 2010 American Chemical Society. Used with permission. 


\title{
Chain- and Regioselective Ethylene and Styrene Dimerization Reactions Catalyzed by a Well-Defined Cationic Ruthenium-Hydride Complex: New Insights on the Styrene Dimerization Mechanism
}

\author{
Do W. Lee \\ Department of Chemistry, Marquette University, \\ Milwaukee, WI \\ Chae S. Yi \\ Department of Chemistry, Marquette University, \\ Milwaukee, WI
}

\begin{abstract}
The cationic ruthenium-hydride complex $\left[\left(\eta^{6}-\right.\right.$ $\left.\mathrm{C}_{6} \mathrm{H}_{6}\right)\left(\mathrm{PCy}_{3}\right)(\mathrm{CO}) \mathrm{RuH}^{+} \mathrm{BF}_{4}{ }^{-}$was found to be a highly regioselective catalyst for the ethylene dimerization reaction to give 2-butene products (TOF $=1910 \mathrm{~h}^{-1},>95 \%$ selectivity for 2 -butenes). The dimerization of styrene exclusively produced the head-to-tail dimer $(E)-\mathrm{PhCH}\left(\mathrm{CH}_{3}\right) \mathrm{CH}=\mathrm{CHPh}$ at an initial turnover rate of $2300 \mathrm{~h}^{-1}$. A rapid

Organometallics, Vol 29, No. 15 (August 9, 2010): pg. 3413-3417. DOI. This article is @ American Chemical Society and permission has been granted for this version to appear in e-Publications@ Marquette. American Chemical Society does not grant permission for this article to be further copied/distributed or hosted elsewhere without the express permission from American Chemical Society.
\end{abstract}


and extensive $\mathrm{H} / \mathrm{D}$ exchange between the vinyl hydrogens of styrene$d_{8}$ and 4-methoxystyrene was observed within 10 min without forming the dimer products at room temperature. The inverse deuterium isotope effect of $k_{H} / k_{D}=0.77 \pm 0.10$ was measured from the first order plots on the dimerization reaction of styrene and styrene- $d_{8}$ in chlorobenzene at $70^{\circ} \mathrm{C}$. The pronounced carbon isotope effect on both vinyl carbons of styrene as measured by using Singleton's method $\left({ }^{13} \mathrm{C}\right.$ (recovered) $/{ }^{13} \mathrm{C}$ (virgin) at $\mathrm{C}_{1}=1.096$ and $\left.\mathrm{C}_{2}=1.042\right)$ indicates that the $\mathrm{C}-\mathrm{C}$ bond formation is the rate-limiting step for the dimerization reaction. The Eyring plot of the dimerization of styrene in the temperature range of $50-90^{\circ} \mathrm{C}$ led to $\Delta H^{\ddagger}=3.3(6) \mathrm{kcal} / \mathrm{mol}$ and $\Delta S^{\ddagger}=-35.5(7)$ e.u. An electrophilic addition mechanism has been proposed for the dimerization of styrene.

\section{Introduction}

Transition metal catalyzed olefin dimerization and oligomerization reactions constitute one of the most important industrial processes for forming a-olefins. $\frac{1-3}{-3}$ Ziegler-type $\mathrm{Ti}$ and $\mathrm{Ni}$ catalysts have been successfully utilized for the commercial processes of ethylene dimerization (IFP Alphabutol process) and a-olefins (Dimersol process), respectively. ${ }^{2}$ Extensive research efforts have led to two distinctively different dimerization reaction mechanisms: CosseArlman mechanism of sequential alkene insertion for Ziegler catalysts, $\underline{1 \mathrm{~d}}, \underline{\underline{2} \mathrm{~b}}$ and the oxidative coupling mechanism via the formation of metallacycles for $\mathrm{Ti}$ and Ta catalysts. $\frac{3}{}$ More recently, Periana and co-workers proposed a novel ethylene dimerization mechanism via vinyl $\mathrm{C}-\mathrm{H}$ activation, which is mediated by an electrophilic Ir-vinyl catalyst on the basis of both experimental and computational analyses. ${ }^{4}$ Since the ethylene oligomerization reaction typically produces a range of olefin products $\left(\mathrm{C}_{4}\right.$ to $\left.\mathrm{C}_{26}\right)$ which require tedious and energy-consuming separation steps, one of the enduring challenges is to design effective catalytic processes that would result in chain- and regioselective olefin products. Chain-selective ethylene trimerization reaction by soluble $\mathrm{Cr}$ and $\mathrm{Ti}$ catalysts has been a notable advance in this context. $\frac{5}{}$

In recent years, considerable research has been focused on utilizing electrophilic late transition metal catalysts to achieve selective

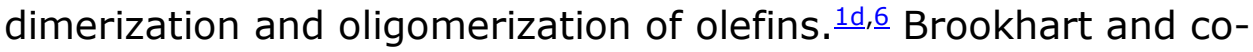
workers investigated detailed kinetic and mechanistic aspects of the 
ethylene dimerization by using a well-defined cationic Pd and Pt catalysts, where the energy of activation for the turnover-limiting olefin insertion step has been estimated to be $19.5 \mathrm{kcal} / \mathrm{mol}$ for cationic (P-N)Pd-alkyl complexes and $29.8 \mathrm{kcal} / \mathrm{mol}$ for (diimine)Pt(II) complexes. ${ }^{7}$ Jordan also found significant steric and electronic effects of the bis(pyrazolyl) and diimine ligands in modulating the activity of cationic (N-N)Pd(II)-alkyl catalysts for the ethylene dimerization and oligomerization reactions. $\stackrel{8}{ }$ While a number of selective formation of 1 butene have been recently reported by using well-defined Ziegler-type catalysts,, 9 most late transition metal catalysts have been found to produce a mixture of 1 - and 2-butenes. $\stackrel{2}{2}$ In a notable case, Roddick reported the regioselective formation of 2-butenes from the ethylene dimerization reaction by using Pt and Pd catalysts with perfluorinated diphosphine ligands under strongly acidic media (340 turnovers/h with 100 psi $\mathrm{C}_{2} \mathrm{H}_{4}$ at $25^{\circ} \mathrm{C}$ ). 10 Regioselective formation of 2-butenes from the dimerization of ethylene is of considerable synthetic importance in homogeneous catalysis, since 2-butenes are a common precursor for both industrially significant SHOP metathesis 11 and Wacker-type olefin oxidation processes. $\underline{12}$

We have recently disclosed that the in-situ formed cationic ruthenium-hydride complexes are highly effective catalysts for the dehydrative coupling reaction of arylketones and 1-alkenes, in which the coupling reactions apparently involved olefin isomerization and vinyl $\mathrm{C}-\mathrm{H}$ activation steps. $\underline{13}$ In an effort to elucidate the coupling reaction mechanism, we have undertaken a series of investigations on the alkene dimerization/oligomerization reactions by using well-defined electrophilic ruthenium-hydride catalysts. This report delineates a highly regio- and chain-selective ethylene and styrene dimerization reaction by using a well-defined cationic ruthenium-hydride catalyst $\left[\left(\eta^{6}-\mathrm{C}_{6} \mathrm{H}_{6}\right)\left(\mathrm{PCy}_{3}\right)(\mathrm{CO}) \mathrm{RuH}^{+} \mathrm{BF}_{4}^{-}(\mathbf{1}) \cdot \underline{14}\right.$

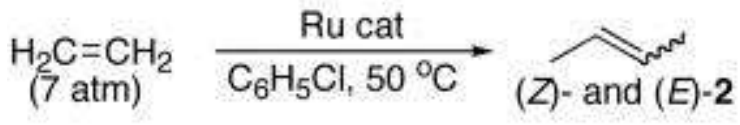

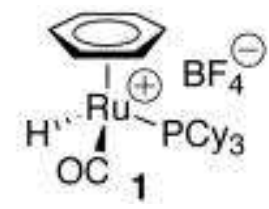

Organometallics, Vol 29, No. 15 (August 9, 2010): pg. 3413-3417. DOI. This article is @ American Chemical Society and permission has been granted for this version to appear in e-Publications@Marquette. American Chemical Society does not grant permission for this article to be further copied/distributed or hosted elsewhere without the express permission from American Chemical Society. 
NOT THE PUBLISHED VERSION; this is the author's final, peer-reviewed manuscript. The published version may be accessed by following the link in the citation at the bottom of the page.

\section{Results and Discussion}

The catalytic activity of selected ruthenium complexes was initially surveyed for the ethylene dimerization reaction. Thus, the treatment of ethylene ( $26 \mathrm{mmol}, 7 \mathrm{~atm})$ and a Ru catalyst $(0.02-0.03$ $\mathrm{mol} \%$ ) in $\mathrm{C}_{6} \mathrm{H}_{5} \mathrm{Cl}$ in a Fisher-Porter pressure tube was stirred at $50{ }^{\circ} \mathrm{C}$ for $30 \mathrm{~min}$ (Eq 1). Initial turnover rate of the dimer and oligomer products was determined by the pressure-volume method from a high vacuum line with $\mathrm{Hg}$-manometer. $\frac{15}{}$ Among the selected ruthenium catalysts, the complex $\mathbf{1}$ exhibited uniquely high activity and selectivity for the formation of 2-butenes (2) over 1-butene and other oligomers as analyzed by both NMR and GC (>95\% selectivity, $(E)$ $2 /(Z)-\mathbf{2}=4: 1$ ) (Table 1). Among initially screened solvents, $\mathrm{C}_{6} \mathrm{H}_{5} \mathrm{Cl}$ was found to be most suitable for the catalyst $1 ; \mathrm{CH}_{2} \mathrm{Cl}_{2}$ was also found to be an acceptable solvent (initial TOF $\sim 1000 \mathrm{~h}^{-1}$ ), but with a considerably lower selectivity for 2-butenes.

Table 1. Catalyst Survey for the Ethylene Dimerization Reaction. ${ }^{a}$

\begin{tabular}{|c|c|c|c|c|}
\hline entry & catalyst & additive & $2(E: Z)^{\mathrm{b}}$ & TOFc \\
\hline 1 & 1 & & $82: 18$ & 1910 \\
\hline $2^{d}$ & {$\left[\mathrm{RuH}(\mathrm{CO})\left(\mathrm{PCy}_{3}\right)\right]_{4}(\mathrm{O})(\mathrm{OH})_{2}$} & & & 0 \\
\hline $3 \underline{d}$ & {$\left[\mathrm{RuH}(\mathrm{CO})\left(\mathrm{PCY}_{3}\right)\right]_{4}(\mathrm{O})(\mathrm{OH})_{2}$} & $\mathrm{HBF}_{4} \cdot \mathrm{OEt}_{2}$ & $70: 30$ & 790 \\
\hline 4 & $\mathrm{RuHCl}(\mathrm{CO})\left(\mathrm{PCy}_{3}\right)_{2}$ & $\mathrm{HBF}_{4} \cdot \mathrm{OEt}_{2}$ & & 0 \\
\hline 5 & $\mathrm{RuH}_{2}(\mathrm{CO})\left(\mathrm{PPh}_{3}\right)_{3}$ & $\mathrm{HBF}_{4} \cdot \mathrm{OEt}_{2}$ & & 20 \\
\hline 6 & $\mathrm{RuCl}_{2}\left(\mathrm{PPh}_{3}\right)_{3}$ & $\mathrm{HBF}_{4} \cdot \mathrm{OEt}_{2}$ & & 0 \\
\hline 7 & {$\left[(p \text {-cymene }) \mathrm{RuCl}_{2}\right]_{2}$} & $\mathrm{HBF}_{4} \cdot \mathrm{OEt}_{2}$ & & 0 \\
\hline 8 & $\mathrm{Ru}_{3}(\mathrm{CO})_{12}$ & $\mathrm{NH}_{4} \mathrm{PF}_{6}$ & & 0 \\
\hline 9 & {$\left[\mathrm{RuH}(\mathrm{CO})\left(\mathrm{PCy}_{3}\right)_{2}\left(\mathrm{CH}_{3} \mathrm{CN}\right)_{2}\right]^{+} \mathrm{BF}_{4}^{-}$} & & & 0 \\
\hline 10 & $\mathrm{RuCl}_{3} \cdot 3 \mathrm{H}_{2} \mathrm{O}$ & & & 0 \\
\hline 11 & $\mathrm{HBF}_{4} \cdot \mathrm{OEt}_{2}$ & & & 0 \\
\hline
\end{tabular}

aReaction conditions: ethylene $(0.74 \mathrm{~g}, 26 \mathrm{mmol})$, catalyst $(5-7 \mathrm{mg}, 0.033 \mathrm{~mol} \%)$, $\mathrm{HBF}_{4} \cdot \mathrm{OEt}_{2}\left(1-2 \mu \mathrm{L}, 1.0\right.$ equiv), $\mathrm{C}_{6} \mathrm{H}_{5} \mathrm{Cl}(1 \mathrm{~mL}), 50^{\circ} \mathrm{C}, 0.5 \mathrm{~h}$.

bDetermined by ${ }^{1} \mathrm{H}$ NMR.

${ }^{\mathrm{CTOF}}=(\mathrm{mol}$ of ethylene consumed $)(\mathrm{mol} \text { of catalyst })^{-1} \mathrm{~h}^{-1}$.

dSee ref. 14a for the synthesis and structure of the complex.

\section{Ethylene Dimerization Reaction}

The catalytic activity of $\mathbf{1}$ for the ethylene dimerization reaction was examined. The rate of formation of the products was measured by $\mathrm{GC}$ in $10 \mathrm{~min}$ intervals from the treatment of ethylene $(0.74 \mathrm{~g}, 26.4$ $\mathrm{mmol}$ ) with 1 (5 mg, $8.7 \mu \mathrm{mol})$ in $\mathrm{C}_{6} \mathrm{H}_{5} \mathrm{Cl}(2 \mathrm{~mL})$ in a $100 \mathrm{~mL}$ Fisher- 
Porter pressure tube at $50^{\circ} \mathrm{C}$. The initial turnover rate, which was measured to be ca. $2440 \mathrm{~h}^{-1}$ after $10 \mathrm{~min}$, was steadily decreased to $1340 \mathrm{~h}^{-1}$ after $1 \mathrm{~h}$, at which time, $45 \%$ of ethylene was converted to 2-butenes. Due to the product inhibition, the reaction rate slowed further giving only about 10000 TON (50\% conversion) after $24 \mathrm{~h}$. The rate of the dimerization reaction was found to be linearly dependent on the pressure of ethylene gas (Figure S1, Supporting Information), and the first order plot of $\operatorname{In}$ [ethylene] vs time resulted in $k_{\mathrm{obs}}=0.76 \mathrm{~h}^{-1}$ (Figure 1).

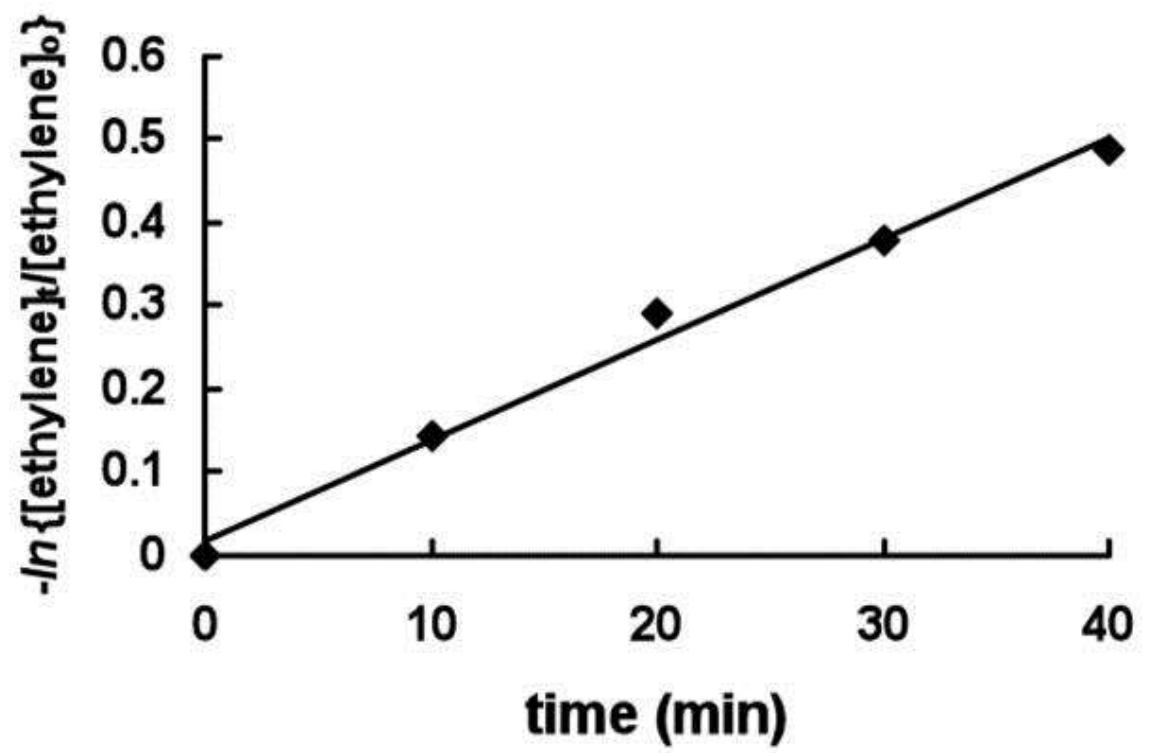

Figure 1. Plot of $\ln \left[\right.$ ethylene] vs time at $50^{\circ} \mathrm{C}$.

In an effort to detect possible intermediate species, the treatment of ethylene ( $4 \mathrm{mg}, 4$ equiv) with $\mathbf{1}(20 \mathrm{mg}, 35 \mu \mathrm{mol})$ in $\mathrm{CD}_{2} \mathrm{Cl}_{2}(0.5 \mathrm{~mL})$ was monitored by NMR. The formation of ethane $(\delta$ $0.23 \mathrm{ppm}$ ) along with small amount of 1 -butene was detected by ${ }^{1} \mathrm{H}$ NMR after 10 min, but no detectable amount of 2-butenes was formed at room temperature. Upon heating to $50{ }^{\circ} \mathrm{C}$, 2-butenes were formed rapidly within $5 \mathrm{~min}$, without changing the amount of 1-butene significantly over time $((E)$ - and $(Z)-\mathbf{2}: 1$-butene $=95: 5)$. Though the formation of free benzene molecule was observed (the ratio of free benzene to coordinated benzene was 35:65 after $10 \mathrm{~min}$ ), we have not been able to detect/identify any new ruthenium species under the conditions.

Organometallics, Vol 29, No. 15 (August 9, 2010): pg. 3413-3417. DOI. This article is @ American Chemical Society and permission has been granted for this version to appear in e-Publications@Marquette. American Chemical Society does not grant permission for this article to be further copied/distributed or hosted elsewhere without the express permission from American Chemical Society. 
To gauge the rate of ethylene dimerization vs olefin isomerization reaction, 1 -pentene $(1.83 \mathrm{~g}, 26 \mathrm{mmol})$ was treated with $1(0.02 \mathrm{~mol} \%)$ in $\mathrm{C}_{6} \mathrm{H}_{5} \mathrm{Cl}$ at $50{ }^{\circ} \mathrm{C}$. The initial turnover rate for the isomerization of 1-pentene to 2-pentenes was found to exceed 20000 $\mathrm{h}^{-1}$, which is an order of magnitude higher than the dimerization rate under the comparable conditions. Also, the catalyst 1 was found to mediate a rapid isomerization of 2-butenes to produce the same mixture as the one formed from the ethylene dimerization reaction $((E)$ - and $(Z)-2: 1$-butene $=94: 6)$. These results showed that the rate of olefin isomerization is much higher than the dimerization reaction, and further suggest that the initially formed 1-alkenes would have been rapidly isomerized under the catalytic reaction conditions.

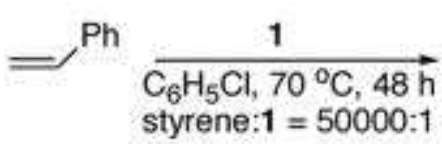

styrene: $1=50000: 1$

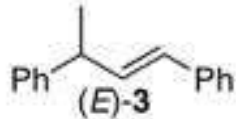

(E)-3 initial TOF $=2300 \mathrm{~h}^{-1}$

TON $=40000$

\section{Styrene Dimerization Reaction}

Among initially screened a-olefins, the catalyst $\mathbf{1}$ was found to be particularly effective for regio- and chain-selective dimerization of styrene and vinylarenes. Thus, the treatment of styrene $(45 \mathrm{~g}, 9.4$ $\mathrm{mmol}$ ) with $\mathbf{1}$ (5 mg, styrene: $\mathbf{1}=50000: 1)$ in $\mathrm{C}_{6} \mathrm{H}_{5} \mathrm{Cl}(1 \mathrm{~mL})$ at $70{ }^{\circ} \mathrm{C}$ led to the head-to-tail dimer product $(E)-3$ exclusively at an initial TOF of $2300 \mathrm{~h}^{-1}$ (Eq 2). No other oligomeric or polymeric products were detected by GC. Furthermore, the catalyst $\mathbf{1}$ was found to be active for a prolong reaction time, giving $\sim 40000$ TON in $48 \mathrm{~h}$. Again, the turnover rate was found to be steadily decreased as the concentration of the dimer product $\mathbf{3}$ is increased. Though regioselective dimerization of styrene and related vinylarenes has been achieved by using electrophilic palladium ${ }^{16}$ and ruthenium ${ }^{17}$ catalysts, the mechanism of the dimerization reaction has not been clearly established. To the best of our knowledge, the activity and selectivity of $\mathbf{1}$ is uniquely high among non-Ziegler type of late transition metal catalysts for the styrene dimerization reaction.

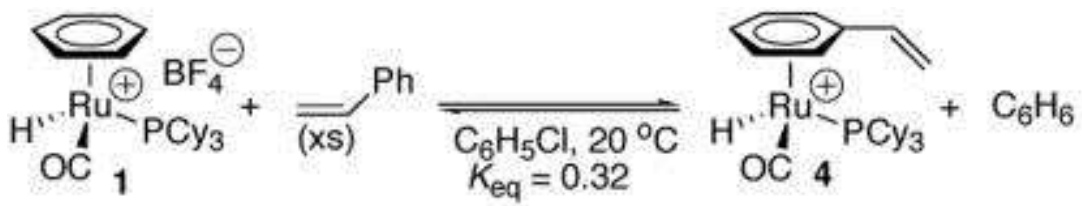

Organometallics, Vol 29, No. 15 (August 9, 2010): pg. 3413-3417. DOI. This article is @ American Chemical Society and permission has been granted for this version to appear in e-Publications@Marquette. American Chemical Society does not grant permission for this article to be further copied/distributed or hosted elsewhere without the express permission from American Chemical Society. 


\section{Kinetics and Mechanistic Study for the Styrene Dimerization Reaction}

We performed the following experiments to gain mechanistic insights on the styrene dimerization reaction. First, the formation of styrene-coordinated complex $\left[\left(\eta^{6}-\mathrm{C}_{6} \mathrm{H}_{5} \mathrm{CH}=\mathrm{CH}_{2}\right) \mathrm{RuH}(\mathrm{CO})\left(\mathrm{PCy}_{3}\right)\right]^{+} \mathrm{BF}_{4}{ }^{-}$ (4) was detected along with ethylbenzene and free benzene molecules when the treatment of styrene $(0.87 \mathrm{mmol})$ with $1(17 \mu \mathrm{mol})$ in $\mathrm{CD}_{2} \mathrm{Cl}_{2}$ $(0.5 \mathrm{~mL})$ was monitored by NMR at $40^{\circ} \mathrm{C}$ (Eq 3$) .15$ Assuming [styrene] remains constant during the exchange reaction, the equilibrium constant $\left(K_{\text {eq }}\right)$ for the reaction was estimated to be 0.32 at $20^{\circ} \mathrm{C}$ from the 31P NMR analysis. Several attempts to isolate the complex 4 in pure form were not successful.

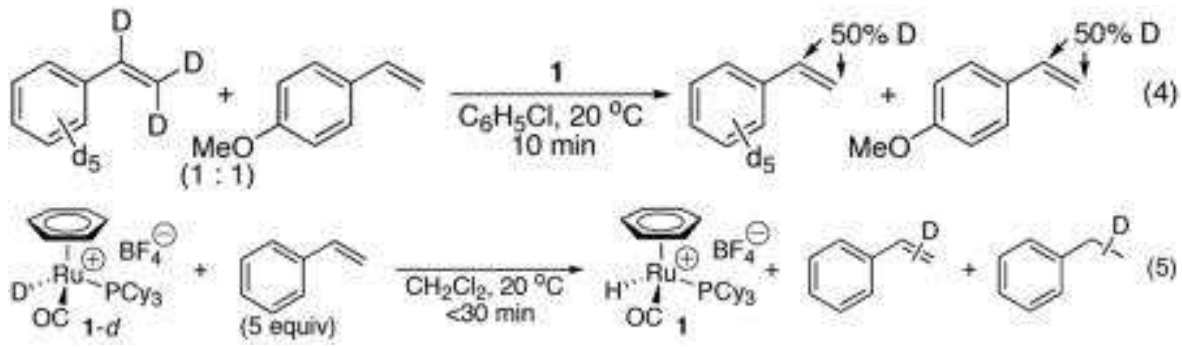

To examine the H/D exchange rate on the alkene substrate, a $1: 1$ mixture of styrene- $d_{8}$ and 4-methoxystyrene $(1.4 \mathrm{mmol})$ in the presence of $1(3 \mathrm{mg})$ in $\mathrm{CH}_{2} \mathrm{Cl}_{2}(0.5 \mathrm{~mL})$ was monitored by NMR at room temperature. A rapid and extensive $\mathrm{H} / \mathrm{D}$ exchange between the vinyl hydrogens of styrene- $d_{8}$ and 4-methoxystyrene was observed within 10 min without forming the dimer products ( $\mathrm{Eq} 4$ ). In a separate experiment, a partially deuterated complex 1-d $(40 \mathrm{mg}, 69$ umol; $64 \%$ Ru-D) was treated with 5 equiv of styrene in $\mathrm{CH}_{2} \mathrm{Cl}_{2}(0.5$ $\mathrm{mL}$ ) at room temperature (Eq 5). A complete $\mathrm{H} / \mathrm{D}$ exchange at the vinyl positions of styrene occurred rapidly within $30 \mathrm{~min}$ at room temperature along with the formation of deuterated ethylbenzene $(33 \% \mathrm{D})$ as monitored by ${ }^{2} \mathrm{H}$ NMR. In this case, the formation of the dimer 3 was observed after $\sim 1 \mathrm{~h}$. The formation of ethylbenzene suggested that the ruthenium-hydride complex $\mathbf{1}$ is acting as a hydrogenation agent, but we have not been able to detect/identify any other ruthenium species under the reaction conditions. 
The deuterium isotope effect of the dimerization reaction was measured under a relatively diluted condition. Thus, the rate of disappearance of styrene was analyzed by GC periodically from the treatment of styrene $(0.54 \mathrm{~g}, 5.2 \mathrm{mmol})$ with $\mathbf{1}(3 \mathrm{mg}, 0.1 \mathrm{~mol} \%)$ in $\mathrm{C}_{6} \mathrm{H}_{5} \mathrm{Cl}(2 \mathrm{~mL})$ at $70^{\circ} \mathrm{C}$. The first order plots of the dimerization reaction rate vs time for both styrene and styrene- $d_{8}$ led to kobs $=$ $0.37 \mathrm{~h}^{-1}$ and $0.48 \mathrm{~h}^{-1}$ respectively, which translated to an inverse isotope effect of $k_{\mathrm{H}} / k_{\mathrm{D}}=0.77 \pm 0.10$ (Figure 2). No significant temperature effect on the isotope effect was observed in the range of $50-90{ }^{\circ} \mathrm{C}$, giving a nearly equal $k_{\mathrm{H}} / k_{\mathrm{D}}=0.67 \pm 0.10$ at $50{ }^{\circ} \mathrm{C}$ and $k_{\mathrm{H}} / k_{\mathrm{D}}$ $=0.68 \pm 0.10$ at $90^{\circ} \mathrm{C}$. In transition metal mediated $\mathrm{C}-\mathrm{H}$ activation reactions, inverse deuterium isotope effects have been commonly observed for the stepwise reactions involving rapid pre-equilibrium followed by a rate-limiting step. $\frac{18}{}$ In our case, the observation of inverse isotope effect on the dimerization reaction is consistent with rapid and reversible styrene coordination and hydride insertion steps followed by a rate-limiting $\mathrm{C}-\mathrm{C}$ bond formation step. $\underline{\underline{19}}$

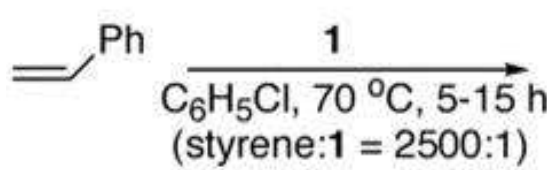

(styrene:1 = 2500:1)

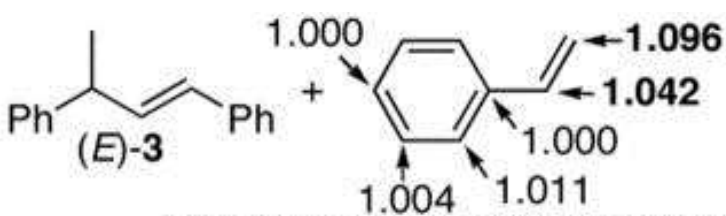

(recovered at $71-88 \%$ conversion )

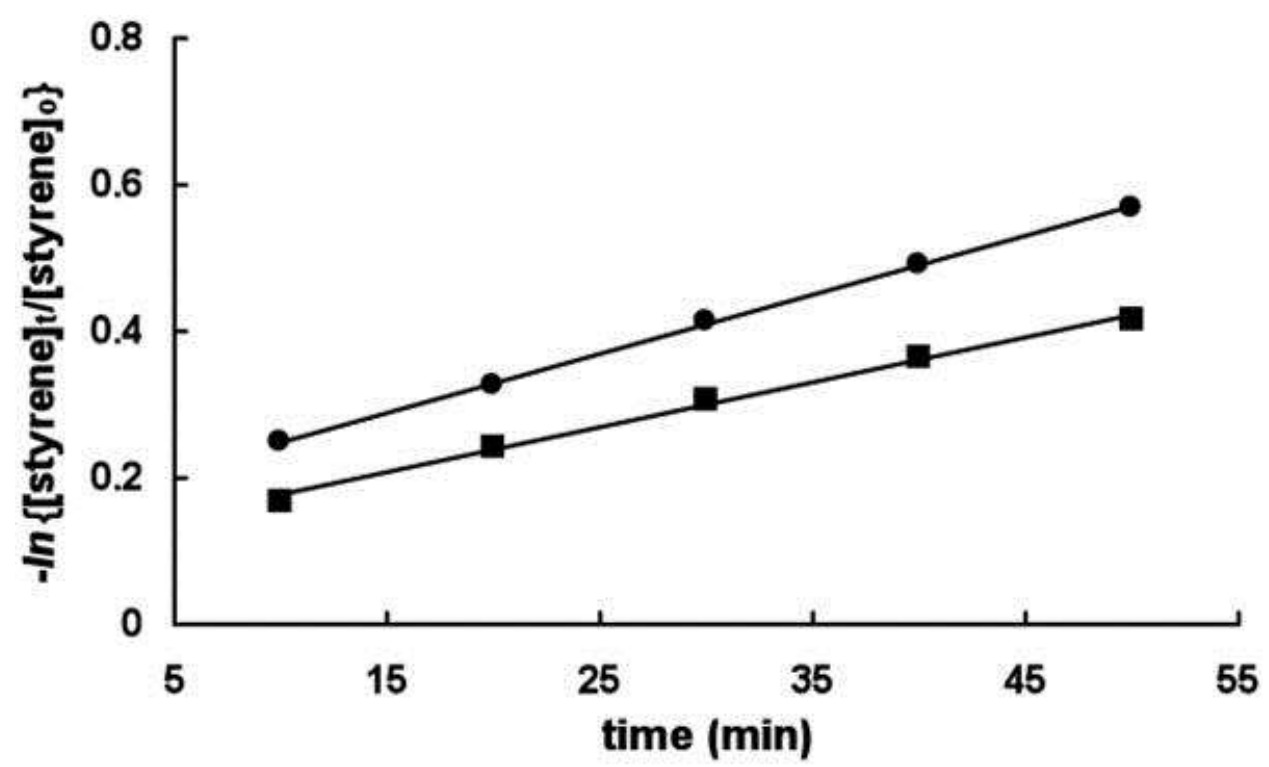

Figure 2 First Order Plots of the Dimerization of Styrene ( $\mathbf{m})$ and Styrene- $d_{8}$ $(\bullet)$ at $70^{\circ} \mathrm{C}$.

Organometallics, Vol 29, No. 15 (August 9, 2010): pg. 3413-3417. DOI. This article is @ American Chemical Society and permission has been granted for this version to appear in e-Publications@Marquette. American Chemical Society does not grant permission for this article to be further copied/distributed or hosted elsewhere without the express permission from American Chemical Society. 
To further discern rate-limiting step of the dimerization reaction, we next examine the carbon isotope effect for the styrene dimerization by employing Singleton's isotope measurement technique at natural abundance. $\underline{20}$ The treatment of styrene $(4.5 \mathrm{~g}, 44 \mathrm{mmol})$ with 1 (10 $\mathrm{mg}, 17 \mu \mathrm{mol})$ in $\mathrm{C}_{6} \mathrm{H}_{5} \mathrm{Cl}(1 \mathrm{~mL})$ at $70{ }^{\circ} \mathrm{C}$ was stopped after $5-15 \mathrm{~h}$ at $71-88 \%$ conversion ( $\mathrm{Eq} 6$ ). The pronounced carbon isotope effect was observed on both vinyl carbons when the ${ }^{13} \mathrm{C}$ ratio of recovered styrene was compared to that of the virgin sample ${ }^{13} \mathrm{C}$ (recovered) $/{ }^{13} \mathrm{C}$ (virgin) at $\mathrm{C}_{\mathrm{q}}=1.096$ and $\mathrm{C}_{2}=1.042$, average of 3 runs)(Table S1, Supporting Information). The observation of carbon isotope effect on both vinyl carbons clearly indicates that the $\mathrm{C}-\mathrm{C}$ bond formation is the rate-limiting step for the dimerization reaction.

An Eyring plot was constructed to determine the thermodynamic parameters for the styrene dimerization reaction (Figure 3 ). The $k_{\text {obs }}$ was determined from a first-order plot of $-\ln \left\{[\text { styrene }]_{t} /[\text { styrene }]_{0}\right\}$ vs time in the treatment of styrene $(0.54 \mathrm{~g}, 5.2 \mathrm{mmol})$ with $1(3 \mathrm{mg}$, $5.2 \mu \mathrm{mol})$ in $\mathrm{C}_{6} \mathrm{H}_{5} \mathrm{Cl}(2 \mathrm{~mL})$ for the temperature range of $50-90^{\circ} \mathrm{C}$. The Eyring plot of $-\ln \left(k_{\mathrm{obs}} / \mathrm{T}\right)$ vs $1 / \mathrm{T}$ led to $\Delta H^{\ddagger}=3.3(6) \mathrm{kcal} / \mathrm{mol}$ and $\Delta S^{\ddagger}=-35.5(7)$ e.u. A relatively large negative $\Delta S^{\ddagger}$ is consistent with an organized transition state formed from combining two styrene molecules.

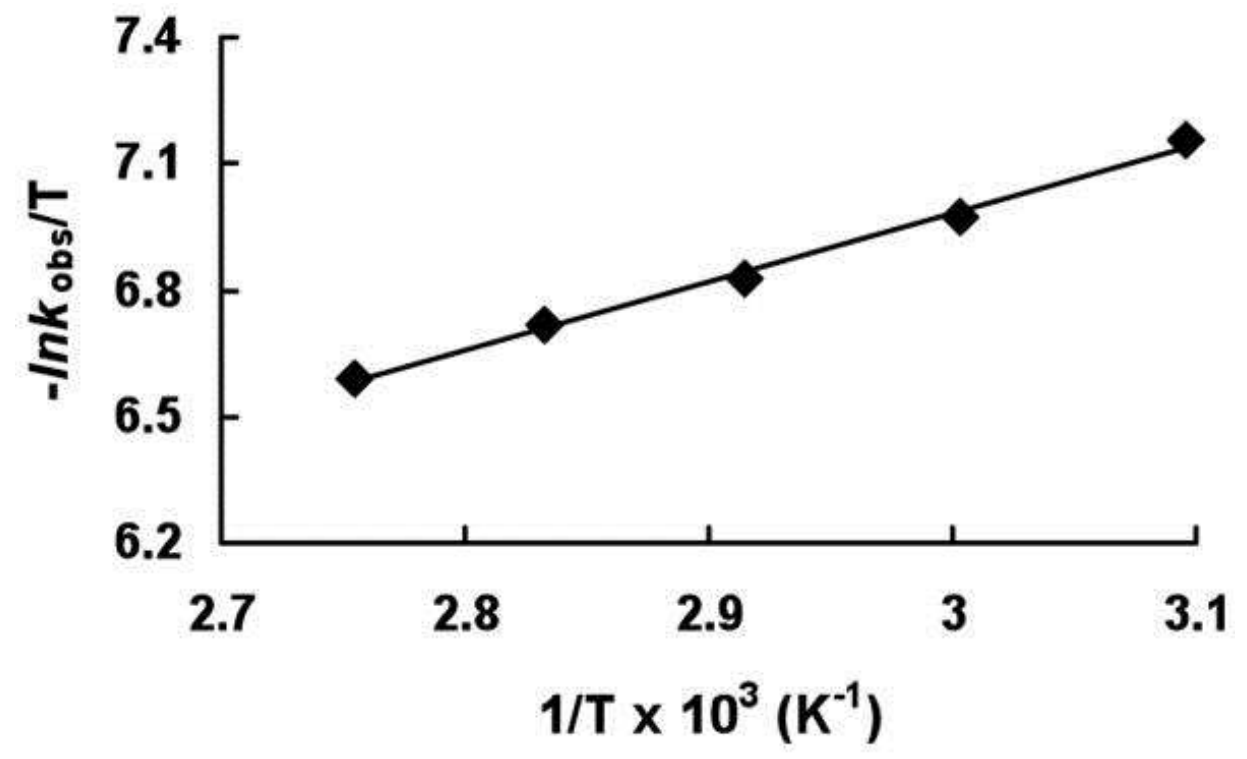

Figure 3. Eyring Plot for the Styrene Dimerization. 


\section{Proposed Mechanism of the Styrene Dimerization Reaction}

These results provide a support for an electrophilic addition mechanism for the styrene dimerization reaction (Scheme 1). We propose that the benzylic carbocation ruthenium-arene species $\mathbf{5}$ is generated from the initial arene exchange reaction and the hydride migration to the coordinated styrene. Both rapid H/D arene exchange results and the observation of styrene complex $\mathbf{4}$ suggest that the initial hydride migration and elimination steps are facile and reversible. The electrophilic addition of the second styrene molecule would form the chain-extended carbocation species $\mathbf{6}$. The inverse deuterium isotope effect and the carbon isotope effect studies implicate that the $\mathrm{C}-\mathrm{C}$ bond formation is the rate-limiting step for the dimerization reaction. The subsequent deprotonation and arene exchange steps should result in the dimer product 3 and the regeneration of the $\mathrm{Ru}-\mathrm{H}$ species 4.

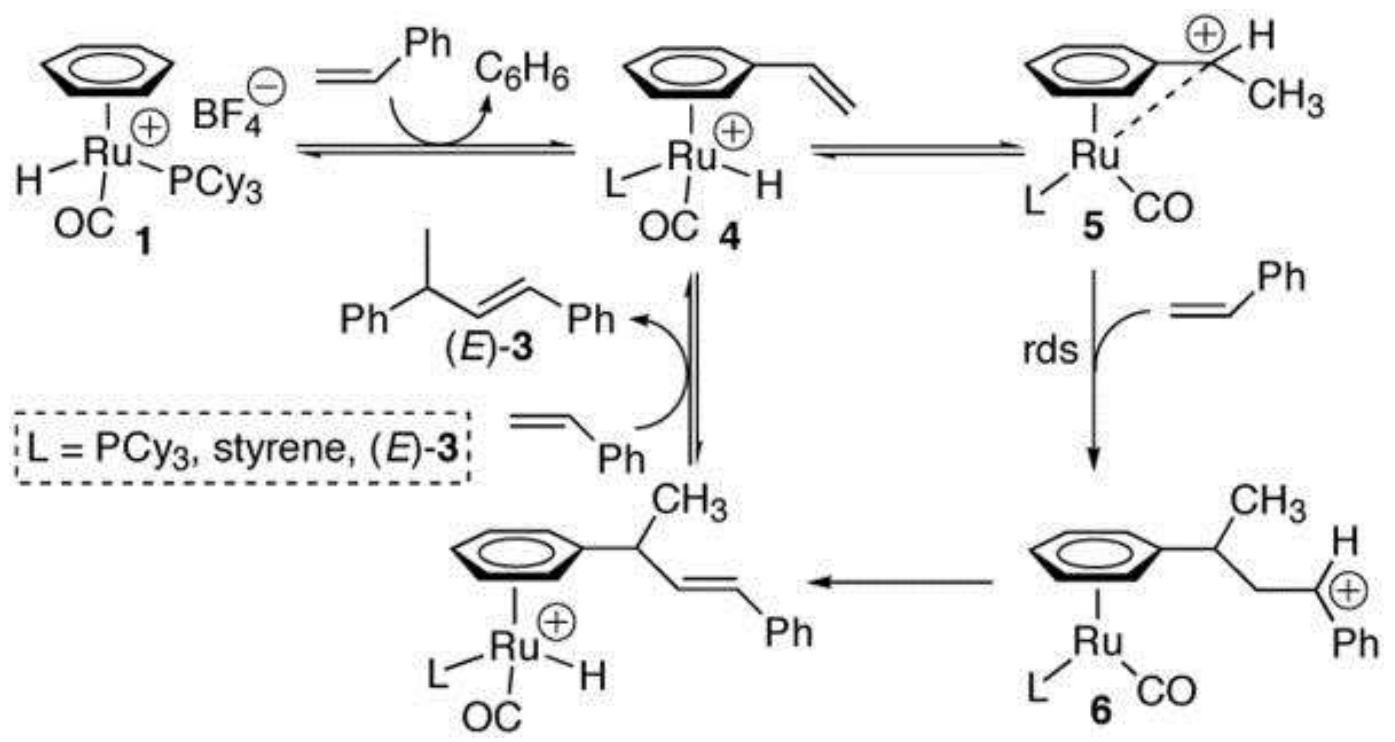

Scheme 1 Proposed Mechanism of the Styrene Dimerization Reaction.

The proposed mechanism can readily explain the exclusive formation of $(E)-3$ product resulted from the deprotonation step of the benzylic carbocation species $\mathbf{6}$ (Scheme 2). From a purely steric point of view, the formation of the "anti" benzyl carbocation species anti-6 would be favored over the "syn" isomer syn-6, and the deprotonation 
of a methylene hydrogen from anti-6 should lead to the trans product $(E)-3$ preferentially. Similar electrophilic addition mechanisms have been commonly proposed for the dimerization/oligomerization reactions mediated by electrophilic metal catalysts, but the reactions typically have been found to give a $E / Z$ mixture of the dimeric products. $\underline{16}$
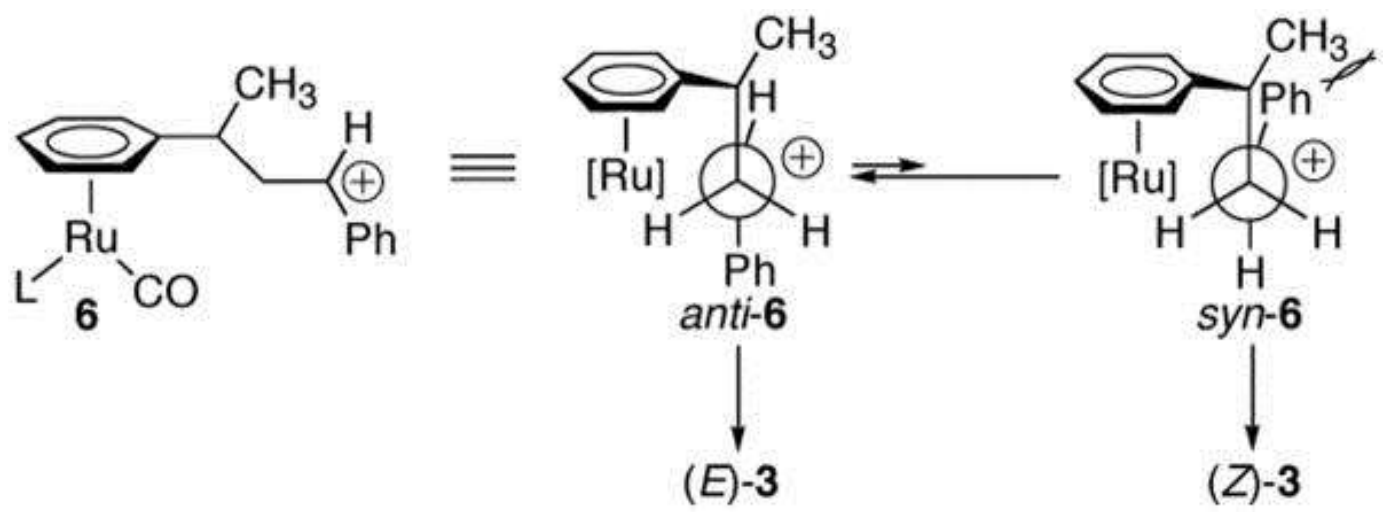

Scheme 2

The Cosse-Arlman type of insertion mechanism is not likely for the styrene dimerization reaction because the mechanism would require a regioselective insertion of the second styrene molecule to form a sterically hindered secondary alkyl species and the subsequent $\beta$ - $\mathrm{H}$ elimination would result in a $E / Z$-mixture of the dimer products. 1,2 Previously, Periana and Goddard proposed a novel dimerization mechanism invoking a vinyl $\mathrm{C}-\mathrm{H}$ activation on the basis of synthetic and computational studies of the ethylene dimerization reaction mediated by electrophilic Ir catalysts. ${ }^{4 a}$ However, in their case, the reaction was performed at a relatively high temperature $\left(150^{\circ} \mathrm{C}\right)$, and the formation of Ru-vinyl species under our reaction conditions (50$70{ }^{\circ} \mathrm{C}$ ) is less likely, though it cannot be rigorously excluded at this time. We also observed that the rate of olefin isomerization is much higher than the ethylene dimerization rate, and this result provides a support for the Cosse-Arlman type of the insertion and isomerization mechanism for the ethylene dimerization reaction. $\underline{\underline{2}}$ It is certainly possible that cationic ruthenium-hydride catalyst $\mathbf{1}$ could operate both vinyl $\mathrm{C}-\mathrm{H}$ activation and Cosse-Arlman insertion/olefin isomerization mechanistic pathways under certain conditions, and we are currently looking into this mechanistic possibility for the ethylene dimerization reaction. 


\section{Conclusions}

A highly efficient and regioselective dimerization of ethylene and styrene has been achieved by using a well-defined cationic rutheniumhydride catalyst $\mathbf{1}$. The kinetic and mechanistic studies for the styrene dimerization reaction provide a support for an electrophilic addition mechanism involving the formation of benzylic carbocation species and the rate-limiting $\mathrm{C}-\mathrm{C}$ bond formation step. Efforts to establish detailed mechanism for the ethylene dimerization reaction as well as to extend the synthetic utility of the dimerization reaction are currently being pursued.

\section{Experimental Section}

\section{Representative Procedure of the Ethylene Dimerization Reaction}

In a glove box, complex $\mathbf{1}(5 \mathrm{mg}, 8.7 \mu \mathrm{mol})$ was dissolved in chlorobenzene $(2 \mathrm{~mL})$ in a $100 \mathrm{~mL}$ Fisher-Porter pressure tube equipped with a magnetic stirring bar. The tube was brought out of the box, and was degassed three times by freeze-pump-thaw cycles. Ethylene gas $(0.74 \mathrm{~g}, 26.4 \mathrm{mmol})$ was condensed into the tube via a vacuum line. The tube was slowly warmed to room temperature and stirred for $30 \mathrm{~min}$ in an oil bath which was preset at $50^{\circ} \mathrm{C}$. After the tube was cooled in a dry ice/ethylene glycol bath $\left(-25^{\circ} \mathrm{C}\right)$ for $10 \mathrm{~min}$, the reaction tube stopcock was slowly open to a vacuum line connected to $\mathrm{Hg}$ manometer. The turnover number was determined by measuring the difference of the vapor pressure exerted by the ethylene gas at $-25^{\circ} \mathrm{C}$. After evaporation of unreacted ethylene at $-25^{\circ} \mathrm{C}$ under a high vacuum, a $\sim 4: 1$ mixture of 2-butene products was obtained ( $>95 \%$ pure as analyzed by NMR and GC).

\section{Deuterium Isotope Effect Study}

In a glove box, complex 1 ( $3 \mathrm{mg}, 5.2 \mu \mathrm{mol})$ and styrene $(0.54$ $\mathrm{g}, 5.2 \mathrm{mmol})$ or styrene- $d_{8}(0.58 \mathrm{~g}, 5.2 \mathrm{mmol})$ were dissolved in chlorobenzene $(2 \mathrm{~mL})$. The solution was divided into equal amounts $(\sim 0.45 \mathrm{~g})$, and each solution was placed into 6 different $25 \mathrm{~mL}$ Schlenk tubes equipped with a Teflon stopcock and a magnetic stirring permission has been granted for this version to appear in e-Publications@ Marquette. American Chemical Society does not grant permission for this article to be further copied/distributed or hosted elsewhere without the express permission from American Chemical Society. 
bar. The tubes were brought out of the box, and were stirred in an oil bath (preset at 50, 70 and $90^{\circ} \mathrm{C}$ ). Each reaction tube was taken out of the oil bath in 10 min intervals, and was immediately cooled in a dry ice/acetone bath. After filtering through a small silica gel column (hexanes/EtOAc $=2: 1$ ), the solution was analyzed by GC to measure the disappearance of the styrene. The $k_{\text {obs }}$ was determined from a first-order plot of - $\ln \left\{[\text { styrene }]_{\mathrm{t}} /[\text { styrene }]_{\mathrm{o}}\right\}$ vs time (Figure S2 and $\underline{\mathrm{S}} \mathbf{)}$.

\section{Carbon Isotope Effect Study}

In a glove box, complex 1 (10 mg, $17.4 \mu \mathrm{mol})$ and styrene $(4.52 \mathrm{~g}, 43.5 \mathrm{mmol})$ were dissolved in chlorobenzene $(1 \mathrm{~mL})$ in three separate $25 \mathrm{~mL}$ Schlenk tubes equipped with a Teflon screw cap stopcock and a magnetic stirring bar. The tubes were brought out of the box, and stirred for 5, 10 and 15 h, respectively, in an oil bath which was preset at $70^{\circ} \mathrm{C}$. After filtering through a small silica gel column (hexanes/EtOAc $=2: 1)$, the solution was analyzed by GC $(71$, 80 and $88 \%$ conversion). Unreacted styrene was collected separately via vacuum transfer for the ${ }^{13} \mathrm{C}\left\{{ }^{1} \mathrm{H}\right\}$ NMR analysis.

The ${ }^{13} \mathrm{C}\left\{{ }^{1} \mathrm{H}\right\}$ NMR analysis of the recovered and virgin samples of styrene was performed by following Singleton's ${ }^{13} \mathrm{C}$ NMR method. $\underline{20}$ The NMR sample of virgin and recovered styrene was prepared identically by dissolving styrene $(100 \mathrm{mg})$ in $\mathrm{CDCl}_{3}(0.5 \mathrm{~mL})$ in a $5 \mathrm{~mm}$ high precision NMR tube. The ${ }^{13} \mathrm{C}\left\{{ }^{1} \mathrm{H}\right\}$ NMR spectra were recorded with $\mathrm{H}$-decoupling and 45 degree pulses. A 60 s delay between pulses was imposed to minimize $T_{1}$ variations $(\mathrm{d} 1=60 \mathrm{~s}$, at $=5.0 \mathrm{~s}, \mathrm{np}=$ 245098, nt $=704)$. The data are summarized in Table S1.

\section{Formation of $\left[\left(\eta^{6}-\mathrm{C}_{6} \mathrm{H}_{5} \mathrm{CH}=\mathrm{CH}_{2}\right) \mathrm{RuH}(\mathrm{CO})\left(\mathrm{PCy}_{3}\right)\right]^{+} \mathrm{BF}_{4}^{-}$} (4)

In a glove box, complex 1 (20 mg, $34.8 \mu \mathrm{mol})$ and styrene (18 mg, 5 equiv) in a J-Young NMR tube equipped with a screw cap were dissolved in $\mathrm{CD}_{2} \mathrm{Cl}_{2}(0.5 \mathrm{~mL})$. The NMR tube was brought out of the box, and was analyzed by both ${ }^{1} \mathrm{H}$ and $31 \mathrm{P}$ NMR in the temperature range of 0 to $50{ }^{\circ} \mathrm{C}$. Two sets of isomers (3:1) for 4 as well as a $\sim 1: 1$ 
ratio of free benzene and ethylbenzene were detected by ${ }^{1} \mathrm{H}$ and $31 \mathrm{P}$ NMR.

Selected spectroscopic data for the major isomer of 4: ${ }^{1} \mathrm{H}$ NMR (400 MHz, $\left.\mathrm{CD}_{2} \mathrm{Cl}_{2}\right) \delta 6.75(\mathrm{~m}, \mathrm{CH}=), 6.6-6.4(\mathrm{~m}, \mathrm{Ar}), 6.04(\mathrm{~d}, \mathrm{~J}=$ $\left.17.5 \mathrm{~Hz},=\mathrm{CH}_{2}\right), 5.65\left(\mathrm{~d}, \mathrm{~J}=10.9 \mathrm{~Hz},=\mathrm{CH}_{2}\right),-10.75\left(\mathrm{~d}, \mathrm{~J}_{\mathrm{PH}}=26.5\right.$ $\mathrm{Hz}, \mathrm{Ru}-\mathrm{H}) ; 31 \mathrm{P}\left\{{ }^{1} \mathrm{H}\right\} \mathrm{NMR}\left(162 \mathrm{MHz}, \mathrm{CD}_{2} \mathrm{Cl}_{2}\right) \delta 73.7$ (s, PCy $)$. Minor isomer of 4: ${ }^{1} \mathrm{H}$ NMR $\left(400 \mathrm{MHz}, \mathrm{CD}_{2} \mathrm{Cl}_{2}\right) \delta-10.66\left(\mathrm{~d}, J_{\mathrm{PH}}=26.4 \mathrm{~Hz}\right.$, $\mathrm{Ru}-\mathrm{H}) ; 31 \mathrm{P}\left\{{ }^{1} \mathrm{H}\right\}$ NMR (162 MHz, $\left.\mathrm{CD}_{2} \mathrm{Cl}_{2}\right) \delta 73.1$ (s, PCy3).

\section{General Procedure for Rate Measurement and Eyring Plot}

In a glove box, complex 1 ( $3 \mathrm{mg}, 5.2 \mu \mathrm{mol})$ and styrene $(0.54$ $\mathrm{g}, 5.2 \mathrm{mmol}$ ) was dissolved in chlorobenzene $(2 \mathrm{~mL})$. The solution was divided into equal amounts ( $0.45 \mathrm{~g})$, and placed in 6 different $25 \mathrm{~mL}$ Schlenk tubes, each equipped with a Teflon stopcock and a magnetic stirring bar. The tubes were brought out of the box, and were stirred in an oil bath preset at 50 to $90{ }^{\circ} \mathrm{C}$. Each reaction tube was taken out of the oil bath in 10 min intervals, and was immediately cooled in a dry ice/acetone bath. After filtering through a small silica gel column (hexanes/EtOAc $=2: 1$ ), the disappearance of the styrene was analyzed by GC. The $k_{\text {obs }}$ was determined from a first-order plot of $-\ln \left\{[\text { styrene }]_{t} /[\text { styrene }]_{0}\right\}$ vs time (Figure S4).

\section{Acknowledgment}

Financial support from the National Institute of Health, General Medical Sciences (R15 GM55987) is gratefully acknowledged.

\section{Footnotes}

Supporting Information Available: Experimental procedures and spectroscopic data of organic products (11 pages, print/PDF). This material is available free of charge via the Internet at http://pubs.acs.org.

\section{References}

${ }^{1}$ Reviews: (a) Pillai SM, Ravindranathan M, Sivaram S. Chem. Rev. 1986;86:353-399.. (b) Skupinska J. Chem. Rev. 1991;91:613-648..

Organometallics, Vol 29, No. 15 (August 9, 2010): pg. 3413-3417. DOI. This article is @ American Chemical Society and permission has been granted for this version to appear in e-Publications@Marquette. American Chemical Society does not grant permission for this article to be further copied/distributed or hosted elsewhere without the express permission from American Chemical Society. 
NOT THE PUBLISHED VERSION; this is the author's final, peer-reviewed manuscript. The published version may be accessed by following the link in the citation at the bottom of the page.

(c) Mecking S. Coord. Chem. Rev. 2000;203:325-351.. (d) Speiser F, Braunstein P, Saussine L. Acc. Chem. Res. 2005;38:784-793.

2 (a) Olivier-Bourbigou $\mathrm{H}$, Saussine L. In: Applied Homogeneous Catalysis with Organometallic Compounds. Cornils B, Herrmann WA, editors. Volume 1. Wiley-VCH; Weinheim: 2002. (b) Keim W. Angew. Chem., Int. Ed. 1990;29:235-244.

3 (a) Keim W, Behr A, Röper M. In: Comprehensive Organometallic Chemistry. Wilkinson G, Stone FGA, Abel EW, editors. Volume 12. Pergamon Press; New York: 1982. (b) Datta S, Fischer MB, Wreford SS. J. Organomet. Chem. 1980;188:353-366. (c) Schrock R, McLain S, Sancho J. Pure Appl. Chem. 1980;52:729-732. (d) Andes C, Harkins SB, Murtuza S, Oyler K, Sen A. J. Am. Chem. Soc. 2001;123:7423-7424. (e) Yu Z-X, Houk KN. Angew. Chem., Int. Ed. 2003;42:808-811.

4 (a) Bhalla G, Oxgaard J, Goddard WA, III, Periana RA. Organometallics. 2005;24:5499-5502. (b) Tsuchimoto T, Kamiyama S, Negoro R, Shirakawa E, Kawakami Y. Chem. Commun. 2003:852-853.

${ }^{5}$ Recent selected examples with Cr catalysts. (a) Dixon JT, Green MJ, Hess FM, Morgan DH. J. Organomet. Chem. 2004;689:3641-3668.. (b) McGuinness DS, Wasserscheid P, Keim W, Morgan D, Dixon JT, Bollmann A, Maumela $H$, Hess F, Englert U. J. Am. Chem. Soc. 2003;125:5272-5273. (c) Blann K, Bollmann A, Dixon JT, Hess FM, Killian E, Maumela $\mathrm{H}$, Morgan DH, Neveling A, Otto S, Overett MJ. Chem. Commun. 2005:620-621. (d) Agapie T, Labinger JA, Bercaw JE. J. Am. Chem. Soc. 2007;129:14281-14295. (e) Arteaga-Müller R, Tsurugi H, Saito T, Yanagawa M, Oda S, Mashima K. J. Am. Chem. Soc. $2009 ; 131: 5370-5371$.

Examples with Ti catalysts: (f) Deckers PJW, Hessen B, Teuben JH. Angew. Chem., Int. Ed. 2001;40:2516-2519. (g) Otten E, Batinas AA, Meetsma A, Hessen B. J. Am. Chem. Soc. 2009;131:5298-5312. (h) Suzuki Y, Kinoshita S, Shibahara A, Ishii S, Kawamura K, Inoue Y, Fujita T. Organometallics. 2010;29:2394-2396..

${ }^{6}$ (a) Ittel SD, Johnson LK, Brookhart M. Chem. Rev. 2000;100:1169-1204.

(b) Mecking S. Angew. Chem., Int. Ed. 2001;40:534-540.

7 (a) DiRenzo GM, White PS, Brookhart M. J. Am. Chem. Soc. 1996;118:6225-6234. (b) Doherty MD, Trudeau S, White PS, Morken JP, Brookhart M. Organometallics. 2007;26:1261-1269. (c) Shiotsuki M, White PS, Brookhart M, Templeton JL. J. Am. Chem. Soc. 2007; 129:4058-4067.

${ }^{8}$ (a) Burns CT, Jordan RF. Organometallics. 2007;26:6726-6736. (b) Conley MP, Burns CT, Jordan RF. Organometallics. 2007;26:6750-6759.

Organometallics, Vol 29, No. 15 (August 9, 2010): pg. 3413-3417. DOI. This article is (C) American Chemical Society and permission has been granted for this version to appear in e-Publications@Marquette. American Chemical Society does not grant permission for this article to be further copied/distributed or hosted elsewhere without the express permission from American Chemical Society. 
${ }^{9}$ (a) Ajellal N, Kuhn MCA, Boff ADG, Hörner M, Thomas CM, Carpentier J-F, Casagrande OL., Jr. Organometallics. 2006;25:1213-1216. (b) Zhang S, Nomura K. J. Am. Chem. Soc. 2010;132:4960-4965.

${ }^{10}$ (a) White S, Bennett BL, Roddick DM. Organometallics. 1999;18:25362542. (b) Basu S, Arulsamy N, Roddick DM. Organometallics. 2008;27:3659-3665.

11 (a) Ivin KJ, Mol JC. Olefin Metathesis and Metathesis Polymerization. Academic Press; London: 1997. (b) Taoufik M, Le Roux E, ThivolleCazat J, Basset J-M. Angew. Chem., Int. Ed. 2007;46:7202-7205.

12 (a) Parshall GW, Ittel SD. Homogeneous Catalysis. 2nd Ed. Wiley; New York: 1992. (b) Jira R. In: Applied Homogeneous Catalysis with Organometallic Compounds. 2nd Ed. Cornils B, Herrmann WA, editors. Vol. 1. Wiley-VCH; Weinheim, Germany: 2002.

${ }^{13}$ (a) Yi CS, Lee DW. Organometallics. 2009;28:4266-4268. (b) Yi CS, Lee DW. Organometallics. 2010;29:1883-1885.

14 (a) Yi CS, Zeczycki TN, Guzei IA. Organometallics. 2006;25:1047-1051. (b) Yi CS, Lee DW. Organometallics. 2009;28:947-949.

15 See the Supporting Information for experimental details.

${ }^{16}$ (a) Jiang Z, Sen A. J. Am. Chem. Soc. 1990;112:9655-9657. (b) Jiang Z, Sen A. Organometallics. 1993;12:1406-1415. (c) Kretschmer WP, Troyanov SI, Meetsma A, Hessen B, Teuben JH. Organometallics. 1998;17:284-286. (d) Yamada S, Obora Y, Sakaguchi S, Ishii Y. Bull. Chem. Soc. Jpn. 2007;80:1194-1198.

17 (a) Kondo T, Takagi D, Tsujita H, Ura Y, Wada K, Mitsudo T. Angew. Chem., Int. Ed. 2007;46:5958-5961. (b) Higashimura M, Imamura K, Yokogawa Y, Sakakibara T. Chem. Lett. 2004;33:728-729.

${ }^{18}$ (a) Jones WD. Acc. Chem. Res. 2003;36:140-146. (b) Parkin G. Acc. Chem. Res. 2009;42:315-325.

${ }^{19}$ We previously observed a similar inverse deuterium isotope effect in ruthenium-catalyzed hydrogenation of olefins: Yi CS, Lee DW. Organometallics. 1999;18:5152-5156..

20 (a) Singleton DA, Thomas AA. J. Am. Chem. Soc. 1995;117:9357-9358. (b) Frantz DE, Singleton DA, Snyder JP. J. Am. Chem. Soc. 1997; 119:3383-3384.

\section{Supplementary Material}

Organometallics, Vol 29, No. 15 (August 9, 2010): pg. 3413-3417. DOI. This article is (C) American Chemical Society and permission has been granted for this version to appear in e-Publications@Marquette. American Chemical Society does not grant permission for this article to be further copied/distributed or hosted elsewhere without the express permission from American Chemical Society. 


\section{Supporting Information}

Chain- and Regioselective Ethylene and Styrene Dimerization Reactions Catalyzed by a Well-Defined Cationic Ruthenium-Hydride Complex: New Insights on the Styrene Dimerization Mechanism

Do W. Lee and Chae S. Yi*

Department of Chemistry, Marquette University, Milwaukee, Wisconsin 53201-1881

$\begin{array}{ll}\text { General Information } & \text { S2 }\end{array}$

Representative Procedure of the Ethylene Dimerization Reaction $\quad$ S2

Representative Procedure of the Styrene Dimerization Reaction S2

Deuterium Isotope Effect Study $\quad$ S3

Carbon Isotope Effect Study $\quad$ S3

Formation of $\left[\left(\eta^{6}-\mathrm{C}_{6} \mathrm{H}_{5} \mathrm{CH}=\mathrm{CH}_{2}\right) \mathrm{RuH}(\mathrm{CO})\left(\mathrm{PCy}_{3}\right)\right]^{+} \mathrm{BF}_{4}^{-}(4) \quad \mathrm{S} 4$

${ }^{1} \mathrm{H}$ and ${ }^{13} \mathrm{C}$ NMR Spectra of Crude Product Mixture of 2-Butenes and (E)-3 S10 
General Information. All operations were carried out in an inert-atmosphere glove box or by using standard high vacuum and Schlenk techniques unless otherwise noted. Tetrahydrofuran, benzene, hexanes and $\mathrm{Et}_{2} \mathrm{O}$ were distilled from purple solutions of sodium and benzophenone immediately prior to use. The NMR solvents were dried from activated molecular sieves (4 $\AA$ ). All organic substrates were received from commercial sources and used without further purification. The ${ }^{1} \mathrm{H},{ }^{2} \mathrm{H},{ }^{13} \mathrm{C}$ and ${ }^{31} \mathrm{P}$ NMR spectra were recorded on a Varian 300 or $400 \mathrm{MHz}$ FT-NMR spectrometer. Mass spectra were recorded from Agilent $6850 \mathrm{GC} / \mathrm{MS}$ spectrometer. The conversion of organic products was measured from a Hewlett-Packard HP 6890 GC spectrometer.

Representative Procedure of the Ethylene Dimerization Reaction. In a glove box, complex $1(5 \mathrm{mg}, 8.7 \mu \mathrm{mol})$ was dissolved in chlorobenzene $(2 \mathrm{~mL})$ in a $100 \mathrm{~mL}$ Fisher-Porter pressure tube (Andrews Glass Co.) equipped with a magnetic stirring bar. The tube was brought out of the box, and was degassed three times by freeze-pump-thaw cycles. Ethylene gas $(0.74 \mathrm{~g}$, $26.4 \mathrm{mmol}$ ) was condensed into the tube via a vacuum line. The tube was slowly warmed to room temperature and stirred for $30 \mathrm{~min}$ in an oil bath which was preset at $50^{\circ} \mathrm{C}$. After the tube was cooled in a dry ice/ethylene glycol bath $\left(-25^{\circ} \mathrm{C}\right)$ for $10 \mathrm{~min}$, the reaction tube stopcock was slowly open to a vacuum line connected to $\mathrm{Hg}$ manometer. The turnover number was determined by measuring the difference of the vapor pressure exerted by the ethylene gas. After evaporation of unreacted ethylene at $-25{ }^{\circ} \mathrm{C}$, a $\sim 4: 1$ mixture of 2-butene products was obtained from the vacuum transfer at $-25^{\circ} \mathrm{C}(>95 \%$ pure as analyzed by NMR and GC).

Representative Procedure of the Styrene Dimerization Reaction. In a glove box, complex $1(5 \mathrm{mg}, 8.7 \mu \mathrm{mol})$ and styrene $(2.71 \mathrm{~g}, 26.0 \mathrm{mmol})$ were dissolved in chlorobenzene (1 $\mathrm{mL}$ ) in a $25 \mathrm{~mL}$ Schlenk tube equipped with a Teflon stopcock and a magnetic stirring bar. The tube was brought out of the box, and was stirred for $30 \mathrm{~min}$ in an oil bath which was preset at 70 ${ }^{\circ} \mathrm{C}$. Reaction tube was taken out of the oil bath, and was immediately cooled in a dry ice/acetone 
bath. After filtering through a small silica gel column (hexanes/EtOAc $=2: 1$ ), the solution was analyzed by GC. Analytically pure styrene dimer $(E)-3$ was isolated after a simple column chromatography on silica gel (hexanes/EtOAc $=40: 1)$.

Deuterium Isotope Effect Study. In a glove box, complex 1 (3 mg, $5.2 \mu \mathrm{mol})$ and styrene $(0.54 \mathrm{~g}, 5.2 \mathrm{mmol})$ or styrene- $d_{8}(0.58 \mathrm{~g}, 5.2 \mathrm{mmol})$ were dissolved in chlorobenzene $(2 \mathrm{~mL})$. The solution was divided into equal amounts $(\sim 0.45 \mathrm{~g})$, and placed into 6 different $25 \mathrm{~mL}$ Schlenk tubes equipped with a Teflon stopcock and a magnetic stirring bar. The tubes were brought out of box, and were stirred in an oil bath (preset at 50, 70 and $90{ }^{\circ} \mathrm{C}$ ). Each reaction tube was taken out of the oil bath in 10 min intervals, and was immediately cooled in a dry ice/acetone bath. After filtering through a small silica gel column (hexanes/EtOAc $=2: 1$ ), the solution was analyzed by GC to measure the disappearance of the styrene. The $k_{\mathrm{obs}}$ was determined from a first-order plot of $-\ln \left\{[\text { styrene }]_{\mathrm{t}} /[\text { styrene }]_{\mathrm{o}}\right\}$ vs time (Figures $2, \mathrm{~S} 2$ and S3).

Carbon Isotope Effect Study. In a glove box, complex 1 (10 mg, $17.4 \mu \mathrm{mol})$ and styrene (4.52 g, $43.5 \mathrm{mmol})$ were dissolved in chlorobenzene $(1 \mathrm{~mL})$ in three separate $25 \mathrm{~mL}$ Schlenk tubes equipped with a Teflon screw cap stopcock and a magnetic stirring bar. The tubes were brought out of the box, and stirred for 5, 10 and $15 \mathrm{~h}$, respectively, in an oil bath which was preset at $70{ }^{\circ} \mathrm{C}$. After filtering through a small silica gel column (hexanes/EtOAc $=2: 1$ ), the solution was analyzed by $\mathrm{GC}(71,80$ and $88 \%$ conversion). Unreacted styrene was collected separately via vacuum transfer for the ${ }^{13} \mathrm{C}\left\{{ }^{1} \mathrm{H}\right\}$ NMR analysis.

The ${ }^{13} \mathrm{C}\left\{{ }^{1} \mathrm{H}\right\}$ NMR analysis of the recovered and virgin samples of styrene was performed by following Singleton's ${ }^{13}$ C NMR method (ref. 20 in the main text). The NMR sample of virgin and recovered styrene was prepared identically by dissolving styrene $(100 \mathrm{mg})$ in $\mathrm{CDCl}_{3}(0.5$ $\mathrm{mL}$ ) in a $5 \mathrm{~mm}$ high precision NMR tube. The ${ }^{13} \mathrm{C}\left\{{ }^{1} \mathrm{H}\right\}$ NMR spectra were recorded with $\mathrm{H}-$ decoupling and 45 degree pulses. A $60 \mathrm{~s}$ delay between pulses was imposed to minimize $\mathrm{T}_{1}$ 
variations $(\mathrm{d} 1=60 \mathrm{~s}$, at $=5.0 \mathrm{~s}, \mathrm{np}=245098, \mathrm{nt}=704)$. The data are summarized in Table S1.

Formation of $\left[\left(\eta^{6}-\mathrm{C}_{6} \mathrm{H}_{5} \mathrm{CH}=\mathrm{CH}_{2}\right) \mathbf{R u H}(\mathrm{CO})\left(\mathrm{PCy}_{3}\right)\right]^{+} \mathrm{BF}_{4}^{-}$(4). In a glove box, complex 1 (20 mg, $34.8 \mu \mathrm{mol}$ ) and styrene (18 mg, 5 equiv) in a J-Young NMR tube equipped with a screw cap were dissolved in $\mathrm{CD}_{2} \mathrm{Cl}_{2}(0.5 \mathrm{~mL})$. The NMR tube was brought out of the box, and was analyzed by both ${ }^{1} \mathrm{H}$ and ${ }^{31} \mathrm{P}$ NMR in the temperature range of 0 to $50{ }^{\circ} \mathrm{C}$. Two isomers of 4 and $\mathrm{a} \sim 1: 1$ ratio of free benzene $(\delta 7.31(\mathrm{~s}))$ and ethylbenzene $\left(\delta 2.70\left(\mathrm{q}, J=7.7 \mathrm{~Hz}, \mathrm{CH}_{2}\right), 1.29(\mathrm{t}, J\right.$ $\left.=7.7 \mathrm{~Hz}, \mathrm{CH}_{3}\right)$ ) were formed as detected by ${ }^{1} \mathrm{H}$ and ${ }^{31} \mathrm{P}$ NMR.

Selected spectroscopic data for the major isomer 4: ${ }^{1} \mathrm{H}$ NMR $\left(400 \mathrm{MHz}, \mathrm{CD}_{2} \mathrm{Cl}_{2}\right) \delta 6.75(\mathrm{~m}$, $\mathrm{CH}=), 6.6-6.4(\mathrm{~m}, \mathrm{Ar}), 6.04\left(\mathrm{~d}, J=17.5 \mathrm{~Hz},=\mathrm{CH}_{2}\right), 5.65\left(\mathrm{~d}, J=10.9 \mathrm{~Hz},=\mathrm{CH}_{2}\right),-10.75\left(\mathrm{~d}, J_{\mathrm{PH}}=\right.$ $26.5 \mathrm{~Hz}, \mathrm{Ru}-\mathrm{H}) ;{ }^{31} \mathrm{P}\left\{{ }^{1} \mathrm{H}\right\}$ NMR (162 MHz, $\left.\mathrm{CD}_{2} \mathrm{Cl}_{2}\right) \delta 73.7(\mathrm{~s}, \mathrm{PCy})$. Minor isomer 4: ${ }^{1} \mathrm{H}$ NMR $\left(400 \mathrm{MHz}, \mathrm{CD}_{2} \mathrm{Cl}_{2}\right) \delta-10.66\left(\mathrm{~d}, J_{\mathrm{PH}}=26.4 \mathrm{~Hz}, \mathrm{Ru}-\mathrm{H}\right) ;{ }^{31} \mathrm{P}\left\{{ }^{1} \mathrm{H}\right\} \mathrm{NMR}\left(162 \mathrm{MHz}, \mathrm{CD}_{2} \mathrm{Cl}_{2}\right) \delta 73.1$ $\left(\mathrm{s}, \mathrm{PCy}_{3}\right)$. 
Figure S1. Effect of pressure on the rate of ethylene dimerization catalyzed by 1 at $50{ }^{\circ} \mathrm{C}$.

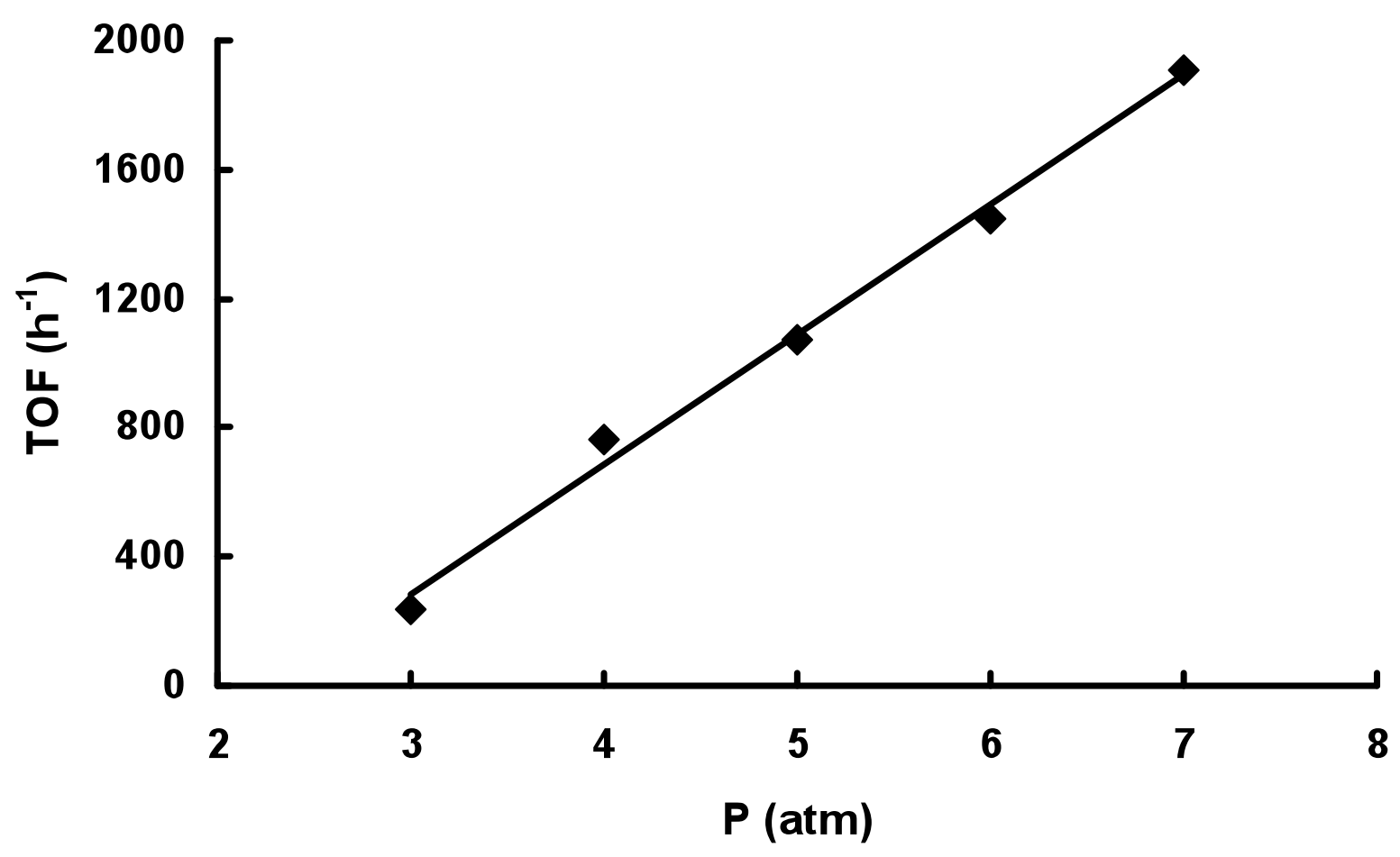


Figure S2. First order plots of the dimerization of styrene $(\boldsymbol{\square})$ and styrene- $d_{8}(\bullet)$ at $50{ }^{\circ} \mathrm{C}$.

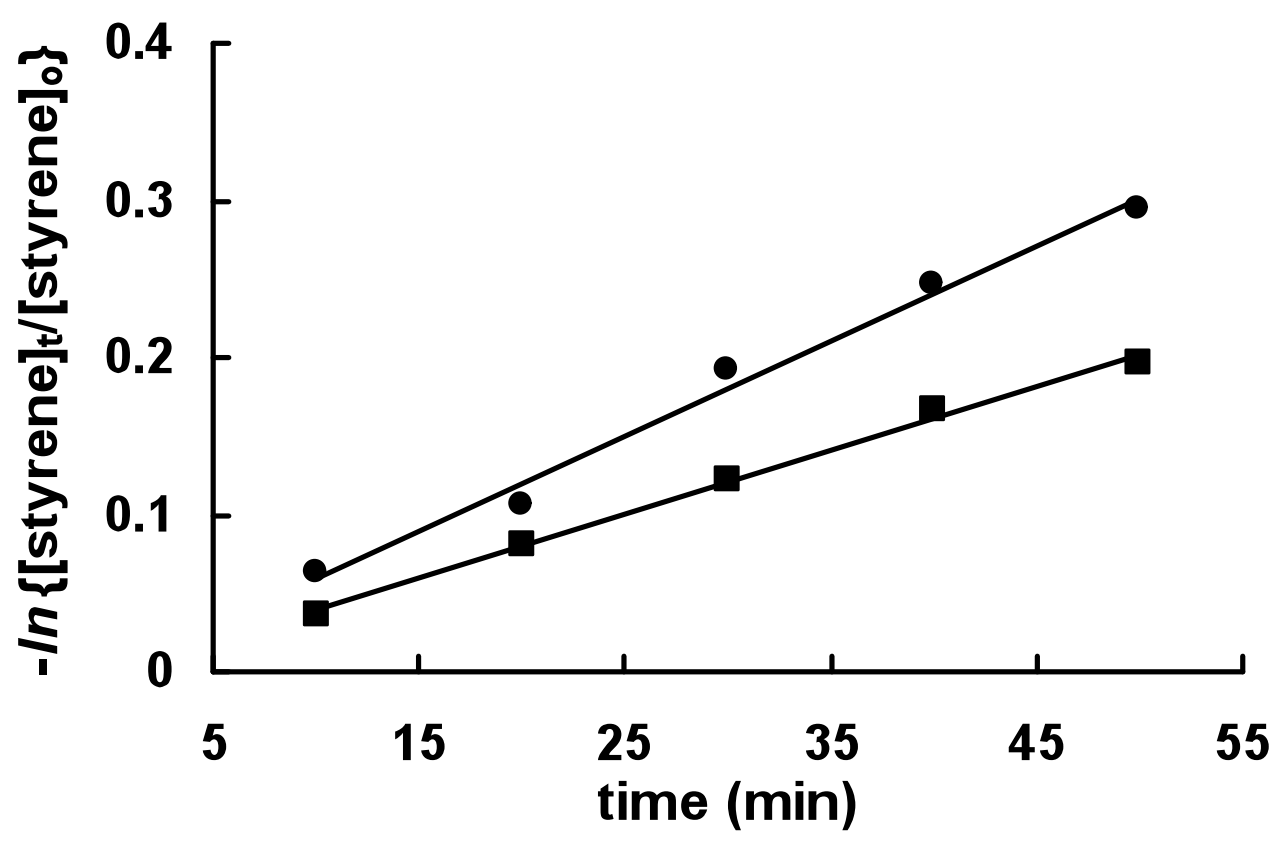


Figure S3. First order plots of the dimerization of styrene (ם) and styrene- $d_{8}(\bullet)$ at $90{ }^{\circ} \mathrm{C}$.

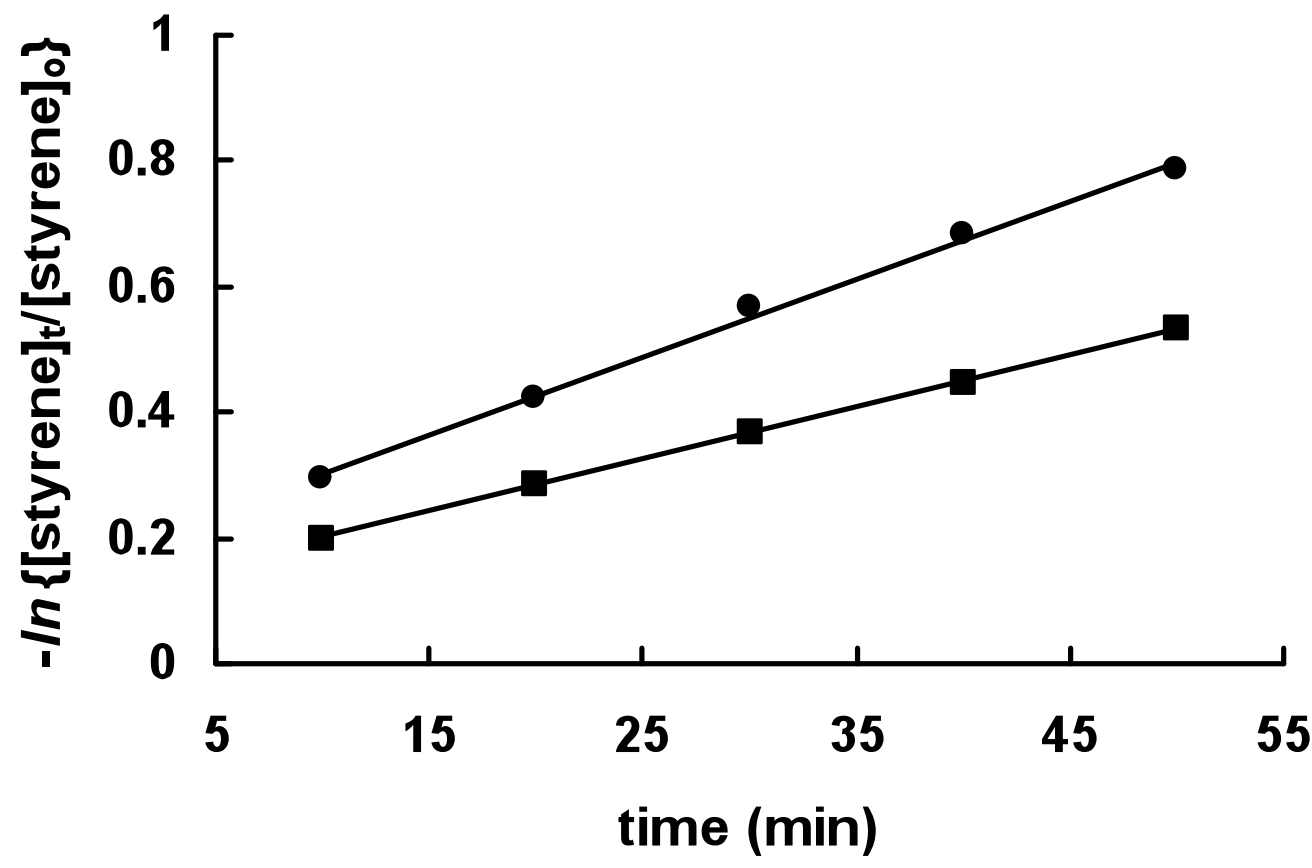


Figure S4. First order plots of the dimerization of styrene at $50{ }^{\circ} \mathrm{C}(+), 60{ }^{\circ} \mathrm{C}(\bullet), 70{ }^{\circ} \mathrm{C}$ $(\boldsymbol{\Delta}), 80^{\circ} \mathrm{C}(\boldsymbol{\bullet})$ and $90^{\circ} \mathrm{C}(\diamond)$.

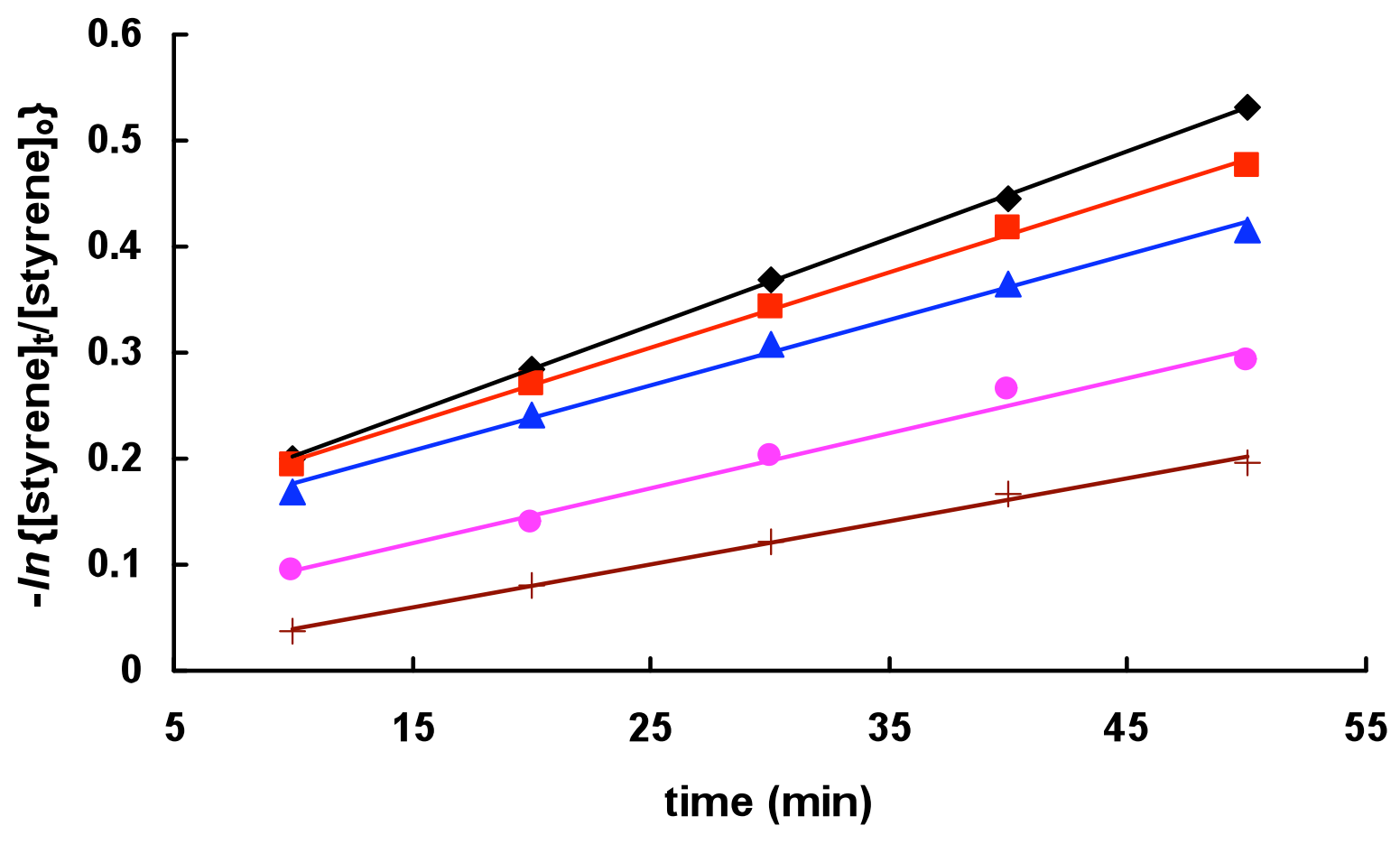




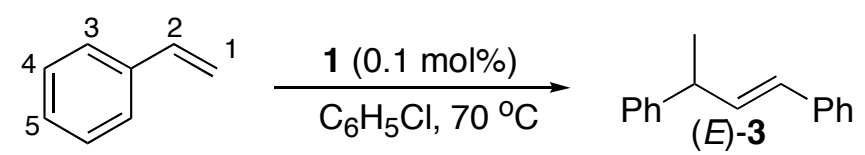

Table Sl. Ave rage ${ }^{13} \mathrm{C}$ Inte grations for Styrene.

\begin{tabular}{llccc}
\hline $\mathrm{C} \#$ & virgin & $\begin{array}{c}\text { recovered } \\
(71 \% \text { conv. })\end{array}$ & recovered/virgin & change (\%) \\
\hline 1 & $0.882(4)$ & $0.954(5)$ & $1.082(5)$ & $+8.2(5)$ \\
2 & $0.907(5)$ & $0.930(5)$ & $1.025(5)$ & $+2.5(5)$ \\
3 & $0.987(5)$ & $0.998(4)$ & $1.011(5)$ & $+1.1(5)$ \\
4 & $0.999(4)$ & $1.004(4)$ & $1.005(5)$ & $+0.5(5)$ \\
$5(\mathrm{ref})$ & $1.000(4)$ & $1.000(4)$ & $1.000(4)$ & $0.0(4)$ \\
\hline
\end{tabular}

\begin{tabular}{|c|c|c|c|c|}
\hline $\mathrm{C} \#$ & virgin & $\begin{array}{c}\text { re covered } \\
(80 \% \text { conv. })\end{array}$ & rec overed/virgin & change (\%) \\
\hline 1 & $0.882(4)$ & $0.967(5)$ & $1.096(5)$ & $+9.6(5)$ \\
\hline 2 & $0.907(5)$ & $0.949(5)$ & $1.046(5)$ & $+4.6(5)$ \\
\hline 3 & $0.987(5)$ & $0.998(4)$ & $1.011(5)$ & $+1.1(5)$ \\
\hline 4 & $0.999(4)$ & $1.003(4)$ & $1.004(5)$ & $+0.4(5)$ \\
\hline $5(\mathrm{ref})$ & $1.000(4)$ & $1.000(4)$ & $1.000(4)$ & $0.0(4)$ \\
\hline
\end{tabular}

\begin{tabular}{llccc}
\hline $\mathrm{C} \#$ & virgin & $\begin{array}{c}\text { rec overed } \\
(88 \% \text { conv.) }\end{array}$ & recoveredkirgin & change (\%) \\
\hline$\vdots 1$ & $0.882(4)$ & $0.979(5)$ & $1.110(5)$ & $+11.0(5)$ \\
2 & $0.907(5)$ & $0.957(5)$ & $1.055(5)$ & $+5.5(5)$ \\
3 & $0.987(5)$ & $1.001(4)$ & $1.014(5)$ & $+1.4(5)$ \\
4 & $0.999(4)$ & $1.012(4)$ & $1.013(5)$ & $+1.3(5)$ \\
$5(\mathrm{ref})$ & $1.000(4)$ & $1.000(4)$ & $1.000(4)$ & $0.0(4)$ \\
\hline
\end{tabular}


The ${ }^{1} \mathrm{H}$ and ${ }^{13} \mathrm{C}$ NMR Spectra of Crude Product Mixture of 2-Butenes.
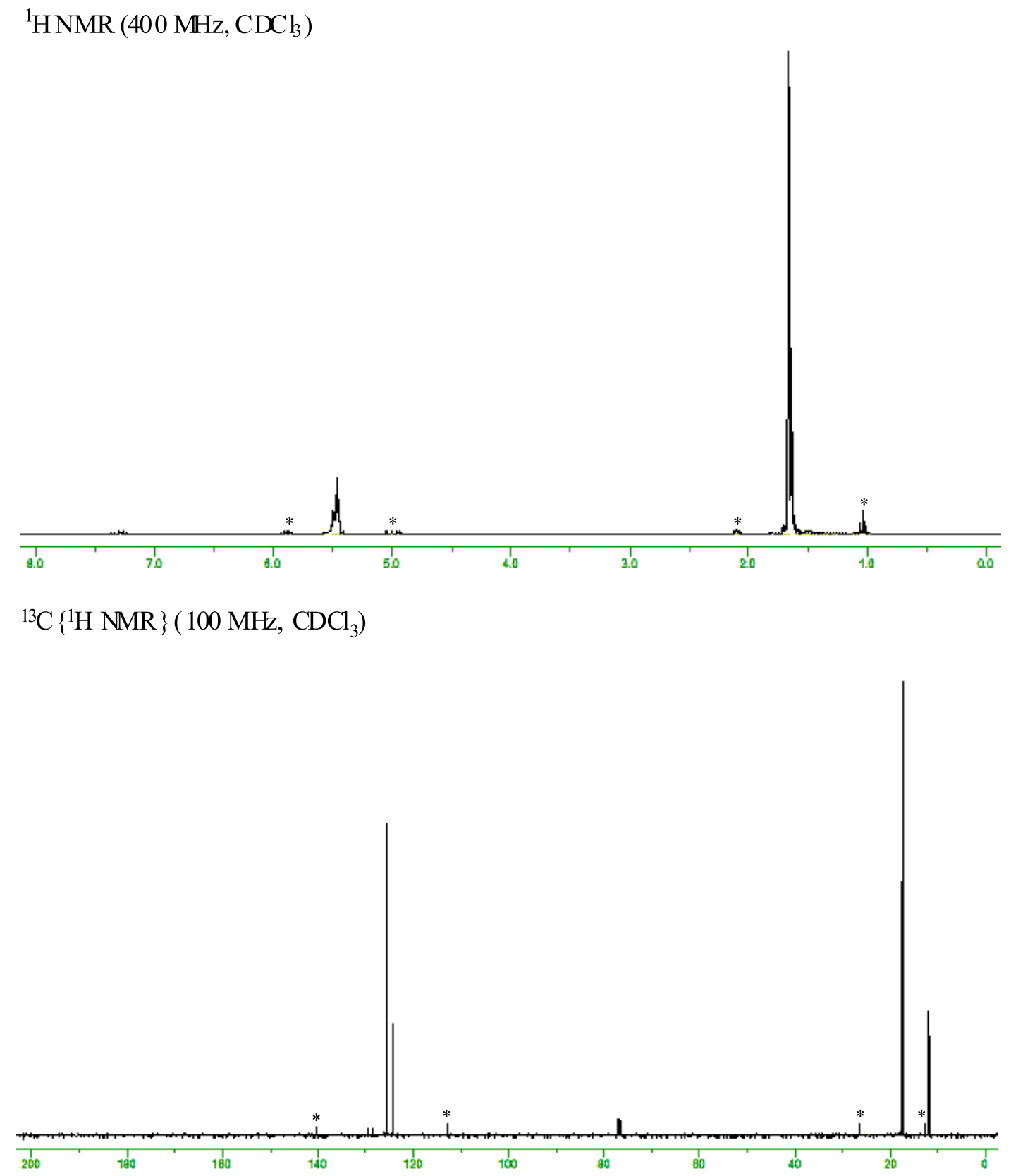

* Denotes 1-butene. 
The ${ }^{1} \mathrm{H}$ and ${ }^{13} \mathrm{C}$ NMR Spectra of $(E)-3$ Obtained from the Dimerization of Styrene.<smiles>CC(C=Cc1ccccc1)c1ccccc1</smiles>

${ }^{l_{\mathrm{H}}} \mathrm{NMR}\left(400 \mathrm{MHz}, \mathrm{CDCl}_{3}\right)$

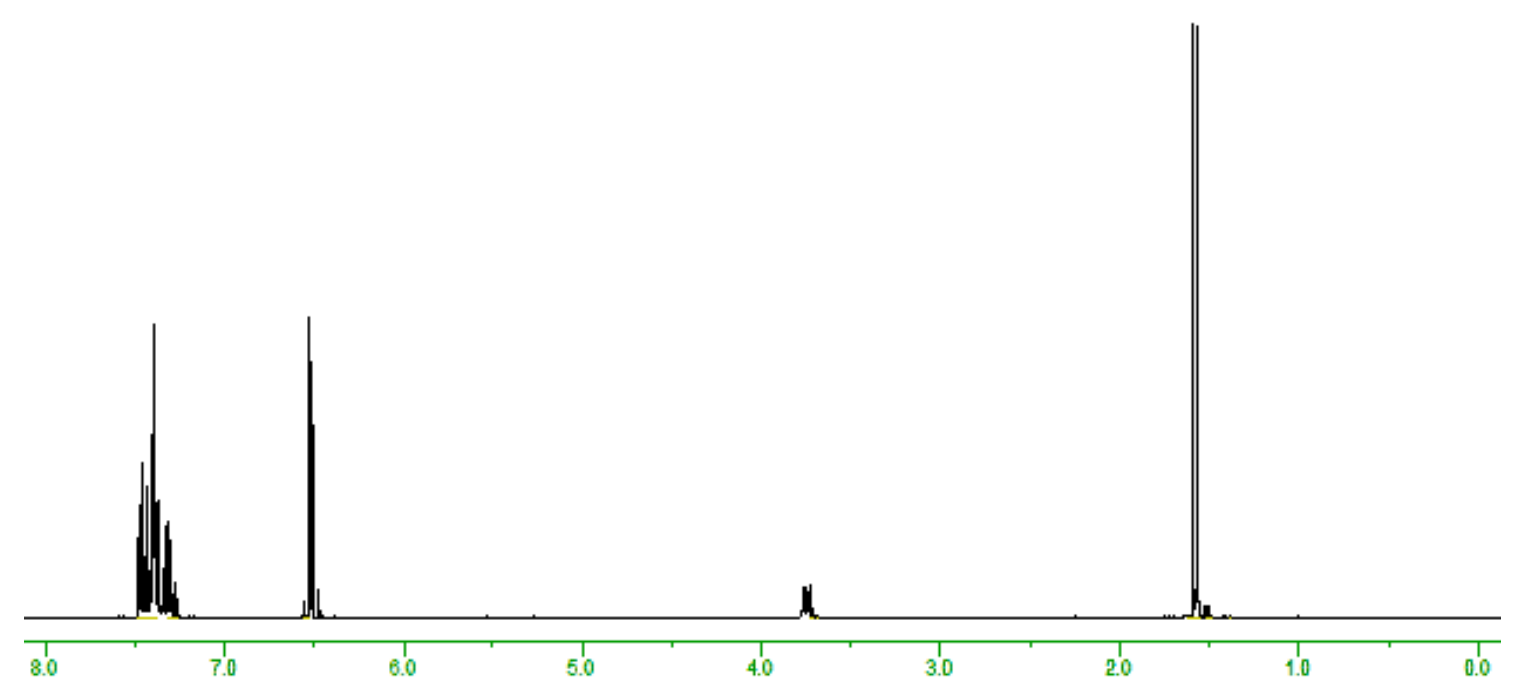

${ }^{13} \mathrm{C}\left\{{ }^{1} \mathrm{H} \mathrm{NMR}\right\}\left(100 \mathrm{MHz}, \mathrm{CDCl}_{3}\right)$

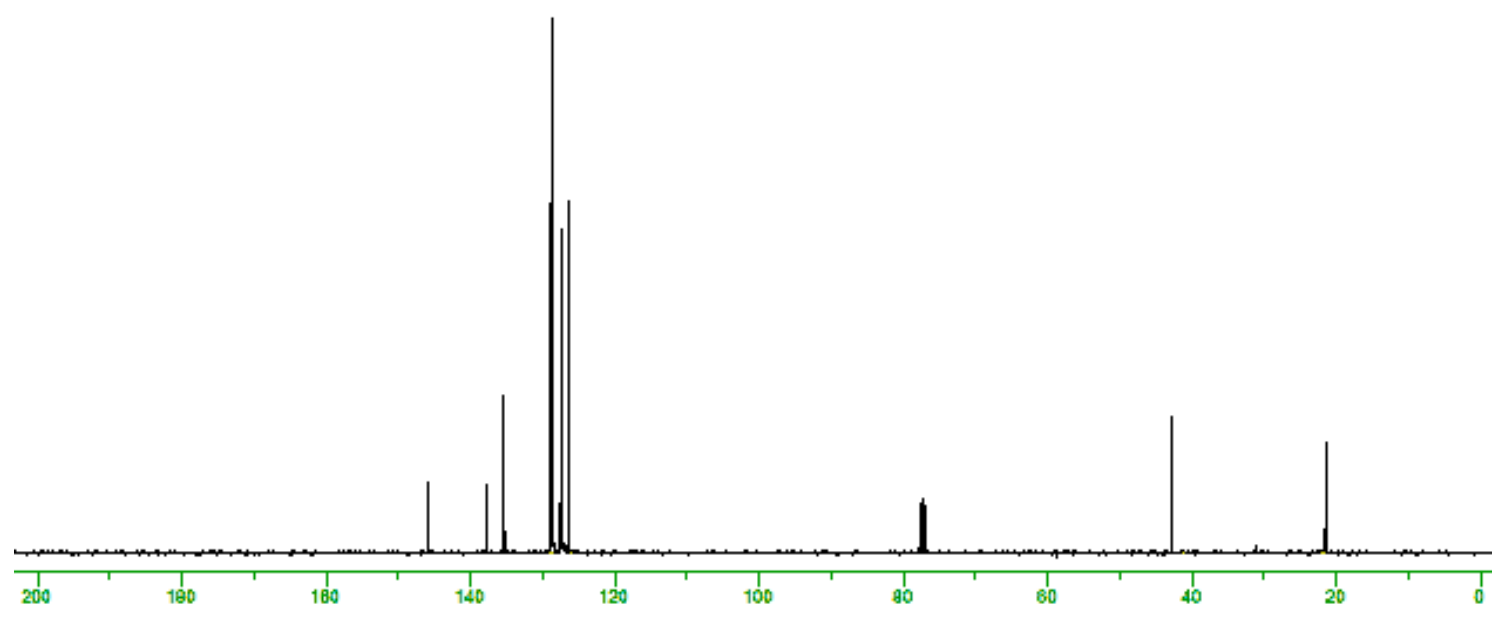

